\title{
Offering methods and issuer-oriented underpricing costs: Evidence from the Hong Kong IPO market
}

\author{
Khelifa Mazouz $^{\mathrm{a}, *}$, Brahim Saadouni $^{\mathrm{b}}$, Shuxing Yin ${ }^{\mathrm{c}}$ \\ a Bradford University School of Management, Bradford University, Bradford, UK \\ ${ }^{b}$ Manchester Business School, The University of Manchester, Manchester, UK \\ c Sheffield Management School, University of Sheffield, Sheffield, UK
}

\section{A R T I C L E I N F O}

\section{Article history:}

Received 25 March 2009

Accepted 28 July 2009

Available online 5 August 2009

\section{JEL classification:}

G3

\section{Keywords:}

Hong Kong initial public offerings

Offering methods

Issuer underpricing cost

Interest on application funds

\begin{abstract}
A B S T R A C T
We extend Leung and Menyah's (2006) study by relating the estimation of the issuer-oriented underpricing costs to the IPO offering methods. We distinguish between the oversubscription rates of institutional and retail investors in the estimation of the issueroriented underpricing costs associated with the pure fixed price, fixed price and bookbuilding IPOs. Leung and Menyah show that the issuer underpricing cost of new share issues $\left(U_{N}\right)$ averages about $14 \%$ of the headline underpricing. This average drops to about $7 \%$ after accounting for the interest income from application funds $\left(R_{A F}\right)$. In this study, we show that the mean of $U_{N}$ is about $16 \%(11 \%)$ of the headline underpricing before (after) accounting for the $R_{A F}$. We report also evidence that the $U_{N}$ and the $R_{A F}$ depend on the IPO offering method. The $U_{N}$ of the pure fixed price, fixed price and bookbuilding IPOs represent $15.60 \%, 4.61 \%$ and $18.07 \%$ of the headline underpricing, respectively. These averages fall to $12.54 \%$, $-4.17 \%$ and $16.67 \%$ after accounting for the $R_{A F}$. Our conclusions are robust across different time periods.
\end{abstract}

(c) 2009 Elsevier B.V. All rights reserved.

\section{Introduction}

The underpricing of initial public offerings (IPOs) is a well documented international phenomenon (Loughran et al., 1994; Ljungqvist and Wilhelm, 2002; Ritter, 2003). Recent studies (Fung et al., 2004; Leung and Menyah, 2006) highlight the importance of accounting for the differences among Asian, US

\footnotetext{
* Corresponding author. Tel.: +44 01274 234349; fax: +44 01274546866.

E-mail addresses: k.mazouz@bradford.ac.uk (K. Mazouz),b.saadouni@manchester.ac.uk (B. Saadouni), shuxing.yin@shef.ac.uk (S. Yin).
} 
and European IPOs when making international comparisons of IPO underpricing. One unique feature of the British, Australian, and most Asian IPOs ${ }^{1}$ is that in the subscription process, (some) investors are required to pay IPO subscription funds without knowing whether or not they would receive an allocation. Unsuccessful and/or partially successful investors receive refund at a face value, without any interest, for the portion of funds not allocated to shares. McGuiness (1993) shows that the underpricing cost of pre-IPO investors forms about 33\% of headline underpricing costs. Fung et al. (2004) report that the interest lost on application funds and other IPO subscription costs in Hong Kong forms between $36 \%$ and $64 \%$ of the IPOs underpricing.

Recently, Leung and Menyah (2006) (hereafter L\&M) extend McGuiness' (1993) work by focusing on the underpricing cost of raising new capital by IPO firms. They use a sample of 163 IPOs from the Hong Kong Stock Exchange (HKSE) over the period 1994-1998 to estimate the underpricing costs associated with new shares issued and sold at IPOs. Whilst estimating the issuer-oriented underpricing costs, L\&M applied a single oversubscription rate (demand multiple) on all shares on offer. As we explain later, L\&M's analysis is valid only for IPOs that were brought to the market using the pure fixed price offering method. Although pure fixed price offerings were the most commonly used in Hong Kong during the period 1994-1998, fixed price and bookbuilding offerings were also widely used.

This study extends the empirical work of L\&M by accounting for the potential impact of the IPO offering methods on the estimation of the issuer underpricing cost of raising new capital by the IPO firms. To allow for a direct comparison with L\&M, we initially base our analysis on 224 Hong Kong IPOs during the period 1994-1998. Then, we examine the period 1999-2007 to check whether our results are time dependent. The 224 IPOs included in our sample represents $99.56 \%$ of all IPOs issued during the period 1994-1998. These IPOs were brought to the market using three different offering methods. Specifically, 135, 32 and 57 of the IPOs were offered using pure fixed price, fixed price and bookbuilding offerings, respectively. Thus, since only 135 are offered using the pure fixed price method, the 163 IPOs in L\&M's study have been brought to the market using more than one offering method. ${ }^{2}$

The Hong Kong IPO subscription processes suggest that the calculation of the amount of interest earned on application funds depends largely on the offering method used. In the case of pure fixed price offering, the underwriter fixes the price and offers the shares to investors at large. This produces one oversubscription rate, which will be applied to all shares on offer in order to estimate the issuerrelated underpricing costs. L\&M base their analysis on the assumption that their sample IPOs were brought to market using a pure fixed price offering method.

In the fixed price offerings, prices are fixed and known prior to the IPO. However, instead of offering the IPO shares to investors at large, offerings are split into two parts; one part is allocated exclusively to institutional investors and the other is offered only to retail investors. This split in offerings results in two oversubscription rates. In the fixed price offering method, unlike the pure fixed price offerings, only retail investors are required to make upfront payment for the shares they apply for. Thus, it is important to apply the retail oversubscription rate only to the shares offered to the retail investors when calculating the interest earned on application funds.

A third common method of IPO offering on the HKSE is bookbuilding offerings. For these offerings, the shares on offer are partitioned between retail and institutional investors. Furthermore, retail investors are required, on application, to pay the upper limit of the price range set out in the prospectus. If the final offer price is set below the upper limit, a refund of application funds is made to unsuccessful and/or partially successful applicants without interest. ${ }^{3}$ The separation between the shares offered to retail investors and those set aside for institutional investors results in two oversubscription rates. Thus, the amount of interest earned on application funds should only be based on the retail oversubscription rate applied to the shares offered to the retail investors. L\&M argue that issuers hardly

\footnotetext{
${ }^{1}$ Hong Kong, India, Indonesia, Malaysia, Singapore and Thailand are among the Asian countries that require advance payment of the application funds (Chowdhry and Sherman, 1996).

2 The population of IPOs brought to the market during 1994-1998 is 225 excluding 2 investments trust and 15 introductions. Thus, even if we assume the IPO missing from our sample was brought to the market using the pure fixed price method, the total number of pure fixed price offerings would only be 136.

${ }^{3}$ Institutional investors pay application funds a day before the shares start trading. Thus, firms that were brought to the market via a bookbuilding route do not earn any interest on application funds from institutional investors.
} 
earn any interest on application funds when the bookbuilding offering method is used. However, we show that issuers' cost savings from the interest earned on upfront payment by retail investors in bookbuilding offerings cannot be ignored.

In this study, we account for the exercise of overallotment options attached to some of the IPOs that were brought to market via fixed price and bookbuilding offerings. Our data reveals that 32 of the IPOs issued during the period 1994-1998 include overallotment options, which were exercised prior to the IPO listings. The exercise of overallotment option affects the size of the offerings and the allocation of shares in IPOs. Specifically, with the overallotment option, underwriters have the right to increase the number of shares offered in the IPO by up to $15 \%$ in order to respond to demand from institutional and/or retail investors. The additional shares offered due to the exercise of overallotment option may either be new or a result of pre-IPO investors selling more of their holdings. In the estimation of the issuer-related underpricing costs, the exercise of overallotment option affects some of the factors, such as the number of new shares issued in the IPO and the total number of shares in issue after the IPO.

L\&M show that the issuer underpricing cost associated with the newly issued shares, during the period 1994-1998, averages about 14\% of the average first day initial returns (headline underpricing). This average shrinks to about $7 \%$ of the headline underpricing when taking into account the interest earned on application funds. In this study, we show that the issuer underpricing cost of new share issues averages about $16 \%$ of the headline underpricing. This average decreases to about $11 \%$ of the headline underpricing when taking into account the interest income from application funds. The issuer underpricing cost of new share issues and the interest income from application funds depends on the IPO offering methods. Specifically, the averages of issuer underpricing cost of new share issues of the pure fixed price, fixed price and bookbuilding IPOs represent $15.60 \%, 4.61 \%$ and $18.07 \%$ of the headline underpricing, respectively. These averages fall to $12.54 \%,-4.17 \%$ and $16.67 \%$ of the headline underpricing, respectively, after accounting for the interest earned on application funds. Consistent with L\&M, and regardless of the offering method, we show that pre-IPO shareholders take necessary steps to minimise wealth transfer to the new shareholders by either selling very small proportions of their holdings or not selling any of their pre-IPO shares when their firm goes public. Our analysis on 334 Hong Kong IPOs issued during the 1999-2007 confirms the validity of our results in the current market conditions.

The rest of paper is structured as follows. Section 2 provides a brief description of our dataset. Section 3 presents our empirical findings. Section 4 verifies the validity of our results over time and Section 5 concludes the paper.

\section{Data}

Our sample includes 558 out of a total 598 IPOs offered in Hong Kong during the period 1994-2007.4 To facilitate comparison with L\&M, we initially examine the period 1994-1998. Then, we repeat our analysis over the period 1999-2007 in order to verify the validity of our conclusions over time. Our sample contains 224 and 334 IPOs offered in Hong Kong during the 1994-1998 and 1999-2007 periods, respectively. The excluded firms were due to the unavailability of the prospectus. Data on issuer characteristics including offer size, offer price, subscription deadline, listing date, and refund date is collected from issue prospectuses, the HKSE fact books, the HKSE website and Bloomberg. Daily closing share prices, local deposit rates and prime lending rates are obtained from DataStream.

\section{Empirical results}

\subsection{An illustrative example}

We use CATIC Shenzhen Holdings Ltd to illustrate the potential biases associated with L\&M's methodology. CATIC was brought to the market via fixed price route. It was first listed on the HKSE

\footnotetext{
4 The population of 598 IPOs excludes a total of 41 IPOs that were brought to market either via introduction or were mutual funds (i.e. investment trusts).
} 
on the 29th of September 1997. The company had 400 million shares in issue before listing. It offered a total of 220 million shares at the IPO; 33 million were set aside for retail investors and 187 million were offered to institutional investors. The shares offered to the retail investors were oversubscribed by 652.58 times whilst the institutional investors' oversubscription was $1 .{ }^{5}$ CATIC had an overallotment option attached with the offer. The overallotment option was fully exercised prior to the first day of trading, causing the number of shares offered to increase to 242 million shares. The first day's market price and offer price associated with CATIC were HK\$3.15 and HK\$1.73, respectively.

We suspect that L\&M's approach applies the oversubscription rate of 652.58 to the entire 220 million shares on offer in order to calculate the interest income on application funds and the issueroriented underpricing costs. Thus, following L\&M's procedure, it can be shown that: (i) the income on application funds based on deposit (prime) rate is HK\$148.03 (HK\$178.7) million; (ii) the interest on application funds $\left(R_{A F} \text { in Eq. (7) }\right)^{6}$ based on deposit (prime) rate is $7.58 \%$ (9.15\%); (iii) the issuer underpricing cost of new shares sold at the IPO $\left(U_{N}\right.$ in Eq. (6)) is $24.79 \%{ }^{7}$ and (iv) the net issuer underpricing cost of new shares sold at the IPO $\left(U_{N E T}\right.$ in Eq. (8)) based on deposit (prime) rate is $17.21 \%(15.64 \%) .^{8}$

We argue that a more accurate approach to estimate the income on application funds $\left(R_{A F}\right), U_{N}$ and $U_{N E T}$ is to apply the oversubscription rate of 652.58 only to the 33 million shares that were set aside for retail investors. Furthermore, ignoring the fact that the exercise of the overallotment option increases the total number of shares offered may cause bias to both $U_{N}$ and $U_{N E T}$ estimates. After controlling for these potential sources of bias, we show that: (i) the income on application funds is HK $\$ 22.05$ million (HK\$26.08) million; (ii) the $R_{A F}$ based on deposit (prime) rate is $1.09 \%$ (1.32\%); (iii) the $U_{N}$ is $27.27 \%$; and (iv) the $U_{N E T}$ based on deposit (prime) rate is $26.18 \%$ (25.95\%).

The above example demonstrates that the approach adopted by L\&M hugely exaggerates the interest income on application funds and underestimates the net issuer underpricing cost of the new shares sold at the IPO.

\subsection{Overall results}

To facilitate comparison with L\&M, we re-estimate Eq. (1) through (8) in L\&M's study, over the period 1994-1994, after adjusting for the potential impact of the IPO offering methods. Table 1 reports the amount left on the period table along with some IPO characteristics and the results from estimating Eq. (1) through (8). The amount left on the table ranges from a negative minimum of HK\$3130.99 million to a positive maximum of HK\$5779.62 million. The mean of the amount left on the table is HK\$59.16 million which represents $9.2 \%$ of the average amount raised. Although most IPOs are underpriced with significant amount left on the table, 33.33\% of the IPOs in our sample are overpriced producing gains to both the issuing firm and pre-IPO investors. The first day initial returns range from $-45 \%$ to $316.67 \%$ with an average of $15.93 \%$. The average oversubscription rates of retail and institutional investors are 69.19 and 6.93, respectively. As stated previously, the estimation of Eq. (1) through (8) is based on a single oversubscription rate applied to all shares on offer in the case of pure fixed price IPOs. However, the retail oversubscription rate is applied only to the shares offered to retail investors in the cases of fixed price and bookbuilding IPOs.

Eq. (4) shows that the underpricing cost to the pre-IPO investors who decide not to sell any of their shares at the IPO $\left(U_{R}\right)$ averages $1.73 \%$, which is just about $11 \%$ of the average first day initial returns of $15.93 \%$. Eq. (5) estimates the underpricing cost to the pre-IPO investors who sell some and retain part of their old shares when new shares are issued $\left(U_{T}\right)$. Our sample contains 35 IPOs in which the pre-IPO shareholders sell part of their holdings along with the newly sold shares by the IPO firm. $U_{T}$ averages to $1.16 \%$, which is lower than the issuers' underpricing cost resulting from the sale of new shares at the IPO. This suggests that pre-IPO shareholders take the necessary steps to minimise the

\footnotetext{
5 The lead underwriter (China Development Finance Co.(H.K.) Ltd.)) reported that the 187 million shares were fully subscribed. We assume that this means that the offer was fully taken up (hence a subscription rate of 1 ).

${ }^{6}$ Note that Eqs. (1) through (8) are shown in L\&M's (2006) study.

${ }^{7} U_{N}=[220,000,000 / 400,000,000] \times[(3.15-1.73) / 3.15]=24.79 \%$.

8 Note that this study is based on the same equations used in L\&M's (2006) study.
} 
Table 1

Sample characteristics, issuer-related underpricing cost, interest earned on application funds for 224 IPOs issued in Hong Kong during the period 1994-1998.

\begin{tabular}{|c|c|c|c|c|c|}
\hline & Mean & Median & Minimum & Maximum & $\mathrm{N}$ \\
\hline Amount Raised (HK\$ m) & 643.43 & 126.50 & 50.00 & 32362.83 & 224 \\
\hline Size of the firm at Po $(\mathrm{HK} \$ \mathrm{~m})^{\mathrm{a}}$ & 2405.64 & 482.40 & 100.00 & 140160.00 & 224 \\
\hline Size of the firm at Pm (HK\$ m) & 2575.43 & 577.25 & 117.00 & 126600.00 & 224 \\
\hline Shares sold as \% of pre-IPO shares (old + new) & 37.58 & 33.33 & 13.00 & 108.45 & 224 \\
\hline Shares sold as \% of pre-IPO shares (old shares) & 10.07 & 7.69 & 1.12 & 31.05 & 36 \\
\hline Amount left on the table (HK\$ m) & 59.16 & 8.12 & -3130.99 & 5779.62 & 224 \\
\hline Demand multiple retail & 69.19 & 9.83 & 0.20 & 1276.00 & 224 \\
\hline Demand multiple institutional & 6.93 & 1.16 & 1.00 & 50.00 & 55 \\
\hline First day initial returns \% & 15.93 & 6.03 & -45.00 & 316.67 & 224 \\
\hline Barry's issuer underpricing cost \% (Eq. (1)) $\left(U_{D}\right)$ & 6.43 & 7.44 & -150.00 & 80.85 & 224 \\
\hline $\begin{array}{l}\text { Issuer underpricing cost of old shares sold without } \\
\text { dilution (Eq. (3)) }\left(U_{S}\right)\end{array}$ & 6.21 & NA & NA & NA & 1 \\
\hline $\begin{array}{l}\text { Issuer underpricing cost of old shares Not sold \% } \\
\text { (Eq. (4)) }\left(U_{R}\right)\end{array}$ & 1.73 & 1.80 & -37.58 & 26.86 & 223 \\
\hline $\begin{array}{l}\text { Issuer underpricing of partial sale of pre-IPO shares } \\
\text { with dilution (Eq. (5)) }\left(U_{T}\right)\end{array}$ & 1.16 & 2.19 & -16.07 & 14.74 & 35 \\
\hline $\begin{array}{l}\text { Issuer underpricing cost of new shares issued and } \\
\text { sold in the IPO \% (Eq. (6)) }\left(U_{N}\right)\end{array}$ & 2.50 & 1.90 & -27.31 & 36.72 & 224 \\
\hline $\begin{array}{l}\text { Interest income on application funds }(\mathrm{HK} \$ \mathrm{~m}) \\
\text { retail deposit rate }\end{array}$ & 8.49 & 0.82 & 0.00 & 218.75 & 224 \\
\hline $\begin{array}{l}\text { Interest Income on application funds (HK\$ m) } \\
\text { retail prime rate }\end{array}$ & 13.38 & 1.38 & 0.00 & 344.33 & 224 \\
\hline $\begin{array}{l}\text { Interest Income as \% of first day firm's market } \\
\text { value retail deposit rate }\end{array}$ & 0.68 & 0.09 & 0.00 & 10.89 & 224 \\
\hline $\begin{array}{l}\text { Interest income as \% of first day firm's market } \\
\text { value retail prime rate }\end{array}$ & 1.09 & 0.14 & 0.00 & 17.14 & 224 \\
\hline $\begin{array}{l}\text { Net issuer underpricing cost (retail only) deposit } \\
\text { rate (Eq. (8)) }\left(U_{N E T}\right)\end{array}$ & 1.81 & 1.38 & -27.32 & 35.82 & 224 \\
\hline $\begin{array}{l}\text { Net issuer underpricing cost (retail only) prime } \\
\text { rate (Eq. (8)) }\end{array}$ & 1.40 & 0.88 & -27.32 & 35.30 & 224 \\
\hline $\begin{array}{l}\text { Deposit rate during the period January } 94 \text { to } \\
\text { December } 98\end{array}$ & 5.47 & 5.37 & 3.06 & 13.50 & 224 \\
\hline $\begin{array}{l}\text { Prime rate during the period January } 94 \text { to } \\
\text { December } 98\end{array}$ & 8.53 & 8.75 & 6.50 & 10.25 & 224 \\
\hline $\begin{array}{l}\text { Number of days between application closing date } \\
\text { and refund date }\end{array}$ & 6.28 & 6.00 & 3.00 & 12.00 & 224 \\
\hline
\end{tabular}

This table reports the characteristics of the 224 IPOs listed on HKSE during the period 1994-1998. Eqs. (1) through (8) are described in Leung and Menyah (2006).

a Po and Pm are the offer price and the first day's market price, respectively. The HK\$ million figures are in nominal terms.

underpricing costs. This argument is further supported by the fact that in only 35 out of the 224 cases pre-IPO shareholders sold part of their old shares whilst their companies sold new shares. Thus, the observed underpricing cost associated with the pre-IPO investors is more likely to be a result of the dilution effect of new share issues rather than from the sale of the shares at the offer price. Eq. (6) suggests that the issuer underpricing cost resulting from the sale of new shares at IPOs $\left(U_{N}\right)$ averages to $2.5 \%$, which is around $16 \%$ of the headline underpricing.

The average income earned on application funds based on the deposit (prime) rate is HK\$8.49 (HK\$13.38) million, forming 14.35\% (22.62\%) of the average amount left on the table. L\&M show that the average income earned on application funds based on deposit (prime) rate is HK\$41.42 (HK\$63.61) million, which makes up 78\% (120\%) of the amount left on the table. Given the dispersion in the values of both the income earned and the amount left on the table, comparing the average of these values may be misleading. Thus, to facilitate the comparison between the income earned and $U_{N}$, we base our analysis on Eq. (7), which expresses income earned as a percentage of the total value of the IPO based on the first day of trading closing price. Based on the deposit rate, the average interest income expressed as a percentage of the value of the firm $\left(R_{A F}\right)$ is $0.68 \%$, which is only $27 \%$ of the average $U_{N}$. 
When the prime rate is used, the company is able to recover $43.6 \%$ of the $U_{N}$ from $R_{A F}$. Eq. (8) shows that the average $U_{N}$ net of average deposit (prime) rate based $R_{A F}$, or average $U_{N E T}$, is $1.81 \%(1.40 \%){ }^{9}$ The average deposit (prime) rate based $U_{N E T}$ makes up $11.36 \%$ (8.79\%) of the headline underpricing. L\&M show that when the deposit (prime) rate is used, average $R_{A F}$ forms $48 \%$ (76\%) of the average $U_{N}$ and the deposit (prime) rate based average $U_{N E T}$ is $1.22 \%(0.57 \%)$. Thus, L\&M hugely overestimate the extent to which issuer underpricing cost is offset by the interest earned on application funds.

\subsection{Results by offering method}

\subsubsection{Pure fixed price offerings}

Panel A of Table 2 reports the results from the 135 pure fixed pricing IPOs issued over the period 1994-1998 sample. The amount of funds raised under this offering method averages to HK\$119.613 million. The average of the amount left on the table is HK $\$ 23.04$ million, representing about $19.26 \%$ of the average amount raised. The first day initial returns range from a minimum of $-45 \%$ to a maximum of $316.67 \%$ with an average of $19.93 \%$. Although most IPOs were underpriced, 40 out of the 135 pure fixed price IPOs (29.62\%) were overpriced, generating positive gains to the issuing companies and pre-IPO shareholders. The average oversubscription rate is 63.97.

Panel A of Table 2 also reports a number of different issuer-related underpricing costs as well as the interest earned on application funds. The average $U_{R}$ is $2.46 \%$, representing $12.34 \%$ of the average first day initial returns of $19.93 \%$. Our pure fixed price IPO sub-sample contains 23 cases in which pre-IPO shareholders sell part of their holdings in conjunction with the newly sold shares by their IPO firms. The average $U_{T}\left(U_{N}\right)$ is $1.86 \%$ (3.11\%), forming $9.23 \%$ (15.6\%) of the average first day initial returns. The fact that average $U_{T}$ is lower than average $U_{N}$ indicates that pre-IPO shareholders time the sale of their holdings in order to minimise their underpricing costs.

The average income earned on application funds for the pure fixed price offerings sub-sample based on the deposit (prime) rate is HK\$6.47 (HK\$10.17) million, representing 5.4\% (8.5\%) of the average amount left on the table. The deposit (prime) rate based average $R_{F A}$ is $0.96 \%$ (1.52\%), representing $30.86 \%$ (48.87\%) of the average $U_{N}$. The average deposit (prime) rate based $U_{N E T}$ is $2.5 \%$ (1.59\%). This average accounts for $12.54 \%$ (7.98\%) of the headline underpricing.

\subsubsection{Fixed price offerings}

In the cases of both fixed price and bookbuiliding IPOs, we account for the exercise of the overallotment options. The exercise of overallotment option affects, among other things, the number of new shares issued in IPO and the total number of shares in issue after the IPO. These, in turn, have direct impact on the different issuer-related underpricing costs estimates.

Panel B of Table 2 presents the results of the 32 fixed price IPOs issued over the period 1994-1998. The average amount raised under the fixed price offering method is HK\$343.01 million. The average amount left on the table associated with this sub-sample is HK\$6.25 million, representing $1.82 \%$ of the total amount raised. The first day initial return averages to $4.56 \%$. Whilst underpricing dominates the fixed price IPO sub-sample, 12 of the 32 IPOs (37.5\%) were overpriced, generating a positive income for the issuing companies and/or pre-IPO shareholders. The oversubscription rates of the retail investors and the institutional investors average to 74.54 and 2.07, respectively. As explained earlier, in the fixed price offerings, only retail investors are required to make upfront payments. Thus, the estimation of the interest earned on application funds and the different issuer-related underpricing costs is based on the retail oversubscription rate applied only to shares offered to the retail investors. $U_{R}, U_{T}$, and $U_{N}$ average to $-0.64 \%,-0.59 \%$ and $0.21 \%$, respectively. This suggests that pre-IPO shareholders, regardless of whether or not they sell part of their holdings at the IPO, enjoy some benefits whilst the issuers of new shares incur a loss of $0.21 \%$. The mean $U_{N}$ represents $4.6 \%$ of the average first day initial returns of $4.56 \%$. Panel B of Table 2 also reports some details on $R_{A F}$ and $U_{N E T}$. The average deposit (prime) rate based $R_{A F}$ is $0.4 \%(0.7 \%)$. This, in turn, results in an average deposit (prime) rate based $U_{N E T}$ of $-0.19 \%$

\footnotetext{
9 The issuer underpricing costs net of deposit (prime) interest income is significantly different from zero with a $p$-value of $0.001(0.011)$.
} 
Table 2

Sample characteristics, issuer-related underpricing costs, and interest earnings on application funds for the pure fixed price, fixed price and bookbuilding IPO sub-samples of 224 IPOs issued in Hong Kong during the period 1994-1998.

\begin{tabular}{|c|c|c|c|c|c|c|c|c|c|c|c|c|c|c|c|c|c|c|}
\hline & \multicolumn{4}{|c|}{ Panel A: pure fixed price } & \multicolumn{5}{|c|}{ Panel B: fixed price } & \multicolumn{5}{|c|}{ Panel C: bookbuilding } & \multicolumn{4}{|c|}{ Panel D: comparing the sub-samples } \\
\hline & Mean & Median & Minimum & Maximum & N & Mean & Median & Minimum & Maximum & N & Mean & Median & Minimum & Maximum & N & $\begin{array}{l}\text { PFP vs. FP } \\
\text { MWT } \\
\text { (p-value) }\end{array}$ & $\begin{array}{l}\text { PFP vs. BB } \\
\text { MWT } \\
\text { ( } p \text {-value) }\end{array}$ & $\begin{array}{l}\text { FP vs. BB } \\
\text { MWT } \\
\text { ( } p \text {-value }) \\
\end{array}$ \\
\hline Amount raised (HKS m) & 119.613 & 86.96 & 42.66 & 1085.78 & 135 & 343.01 & 223.02 & 44.01 & 1484.41 & 32 & 1848.30 & 1155.38 & 223.83 & 28141.60 & 57 & $-3.22(0.00)$ & $-10.71(0.00)$ & $-6.14(0.00)$ \\
\hline $\begin{array}{l}\text { Size of the firm at Po } \\
(\mathrm{HKS} \mathrm{m})^{\mathrm{a}}\end{array}$ & 468.14 & 345.91 & 85.32 & 4343.11 & 135 & 1154.86 & 797.72 & 149.21 & 5937.63 & 32 & 6920.00 & 3567.21 & 470.44 & 121878.00 & 57 & $-3.11(0.00)$ & $-10.56(0.00)$ & $-6.26(0.00)$ \\
\hline $\begin{array}{l}\text { Size of the firm at Pm } \\
\text { (HKS m) }\end{array}$ & 558.64 & 379.67 & 99.83 & 4364.82 & 135 & 1162.12 & 684.94 & 136.18 & 517.67 & 32 & 7316.00 & 4445.76 & 506.91 & 110087.00 & 57 & $-2.61(0.00)$ & $-10.33(0.00)$ & $-6.16(0.00)$ \\
\hline $\begin{array}{l}\text { Shares sold as \% of } \\
\text { pre-IPO shares } \\
\text { (old + new) }\end{array}$ & 34.39 & 33.33 & 25.43 & 100.00 & 135 & 38.69 & 33.33 & 30.3 & 80.72 & 32 & 44.50 & 40.35 & 13.00 & 108.45 & 57 & $-2.52(0.01)$ & $-5.16(0.00)$ & $-1.82(0.07)$ \\
\hline $\begin{array}{l}\text { Shares sold as \% of } \\
\text { pre-IPO shares (old } \\
\text { shares) }\end{array}$ & 9.24 & 7.69 & 6.25 & 19.89 & 23 & 10.42 & 7.99 & 3.23 & 23.75 & 8 & 13.28 & 8.08 & 1.12 & 31.05 & 5 & $-0.26(0.79)$ & $-0.31(0.97)$ & $0.00(1.00)$ \\
\hline $\begin{array}{l}\text { Amount left on the table } \\
(\mathrm{HKS} \mathrm{m})\end{array}$ & 23.04 & 7.25 & -47.32 & 400.71 & 135 & 6.25 & 2.44 & -229.15 & 301.17 & 32 & 154.14 & 38.48 & -2723.00 & 5146.59 & 57 & $-1.70(0.09)$ & $-1.45(0.14)$ & $-1.56(0.12)$ \\
\hline Demand multiple retail & 63.97 & 10.40 & 0.42 & 892.00 & 135 & 74.54 & 3.00 & 0.2 & 652.58 & 32 & 78.53 & 9.69 & 0.77 & 1276.00 & 57 & $-1.28(0.20)$ & $-0.58(0.56)$ & $-1.37(0.17)$ \\
\hline $\begin{array}{l}\text { Demand multiple } \\
\text { institutional }\end{array}$ & - & - & - & - & - & 2.07 & 1.00 & 1 & 15.00 & 15 & 8.90 & 3.00 & 1.00 & 50.00 & 40 & - & - & $-3.13(0.00)$ \\
\hline First day initial returns \% & 19.93 & 10.40 & -45.00 & 316.67 & 135 & 4.56 & 3.68 & -32.02 & 82.08 & 32 & 12.84 & 2.00 & -38.66 & 222.12 & 57 & $-2.16(0.03)$ & $-1.83(0.07)$ & $-0.49(0.62)$ \\
\hline $\begin{array}{l}\text { Barry's issuer } \\
\text { underpricing cost \% } \\
\text { (Eq. (1))(UD) }\end{array}$ & 9.89 & 12.30 & -150.00 & 80.85 & 135 & -3.00 & 4.81 & -102.37 & 57.38 & 32 & 3.55 & 2.61 & -106.4 & 77.29 & 57 & $-2.02(0.04)$ & $-1.70(0.09)$ & $-0.44(0.66)$ \\
\hline $\begin{array}{l}\text { Issuer underpricing cost } \\
\text { of old shares sold } \\
\text { without dilution (Eq. } \\
(3))\left(U_{S}\right)\end{array}$ & $\mathrm{NA}$ & NA & NA & NA & 0 & NA & NA & NA & NA & 0 & 0.06 & NA & NA & NA & 1 & NA & NA & NA \\
\hline $\begin{array}{l}\text { Issuer underpricing cost } \\
\text { of old shares Not sold } \\
\%\left(\text { Eq. (4)) }\left(U_{P}\right)\right.\end{array}$ & 2.46 & 2.72 & -37.50 & 20.21 & 135 & -0.67 & 1.12 & -37.58 & 22.40 & 32 & 1.32 & 0.71 & -26.59 & 26.86 & 57 & $-1.80(0.07)$ & $-1.33(0.18)$ & $-0.39(0.69)$ \\
\hline $\begin{array}{l}\text { Issuer underpricing of } \\
\text { partial sale of pre-IPO } \\
\text { shares with dilution } \\
(\text { Eq. }(5))\left(U_{T}\right)\end{array}$ & 1.86 & 2.35 & -16.07 & 14.74 & 23 & -0.59 & 2.62 & -15.45 & 4.09 & 8 & 0.65 & 0.26 & -0.72 & 2.82 & 4 & $-0.44(0.46)$ & $-1.36(0.17)$ & $-0.51(0.61)$ \\
\hline $\begin{array}{l}\text { Issuer underpricing cost } \\
\text { of New shares issued } \\
\text { and sold in the IPO \% } \\
(\text { Eq. }(6))\left(U_{N}\right)\end{array}$ & 3.11 & 2.80 & -27.27 & 25.33 & 135 & 0.21 & 1.20 & -27.31 & 28.86 & 32 & 2.32 & 0.70 & -21 & 36.72 & 57 & $-1.78(0.07)$ & $-1.42(0.15)$ & $-0.36(0.72)$ \\
\hline $\begin{array}{l}\text { Interest income on } \\
\text { application funds (HKS } \\
\text { m) retail deposit rate }\end{array}$ & 6.47 & 1.24 & 0.00 & 82.11 & 135 & 6.02 & 0.17 & 0 & 57.95 & 32 & 12.06 & 0.99 & 0.04 & 194.79 & 57 & $-2.08(0.03)$ & $-0.67(0.50)$ & $-2.47(0.01)$ \\
\hline
\end{tabular}


Table 2 (Continued)

\begin{tabular}{|c|c|c|c|c|c|c|c|c|c|c|c|c|c|c|c|c|c|c|}
\hline & \multicolumn{4}{|c|}{ Panel A: pure fixed price } & \multicolumn{5}{|c|}{ Panel B: fixed price } & \multicolumn{5}{|c|}{ Panel C: bookbuilding } & \multicolumn{4}{|c|}{ Panel D: comparing the sub-samples } \\
\hline & Mean & Median & Minimum & Maximum & N & Mean & Median & Minimum & Maximum & $N$ & Mean & Median & Minimum & Maximum & N & $\begin{array}{l}\text { PFP vs. FP } \\
\text { MWT } \\
\text { ( } p \text {-value) }\end{array}$ & $\begin{array}{l}\text { PFP vs. BB } \\
\text { MWT } \\
\text { ( } p \text {-value) }\end{array}$ & $\begin{array}{l}\text { FP vs. BB } \\
\text { MWT } \\
\text { ( } p \text {-value) }\end{array}$ \\
\hline $\begin{array}{l}\text { Interest income on } \\
\text { application funds (HKS } \\
\text { m) retail prime rate }\end{array}$ & 10.17 & 1.90 & 0.00 & 128.33 & 135 & 10.34 & 0.31 & 0 & 117.19 & 32 & 18.95 & 1.71 & 0.08 & 306.62 & 57 & $-2.11(0.03)$ & $-0.69(0.49)$ & $-2.46(0.01)$ \\
\hline $\begin{array}{l}\text { Interest income as \% of } \\
\text { first day firm's market } \\
\text { value retail deposit } \\
\text { rate }\end{array}$ & 0.96 & 0.24 & 0.00 & 10.89 & 135 & 0.40 & 0.03 & 0 & 3.82 & 32 & 0.18 & 0.03 & 0.00 & 1.58 & 57 & $-3.94(0.00)$ & $-5.85(0.00)$ & $-0.89(0.37)$ \\
\hline $\begin{array}{l}\text { Interest income as \% of } \\
\text { first day firm's market } \\
\text { value retail prime rate }\end{array}$ & 1.52 & 0.40 & 0.00 & 17.14 & 135 & 0.73 & 0.04 & 0 & 7.73 & 32 & 0.29 & 0.05 & 0.00 & 2.49 & 57 & $-4.00(0.00)$ & $-5.88(0.00)$ & $-0.77(0.44)$ \\
\hline $\begin{array}{l}\text { Net issuer underpricing } \\
\text { cost (retail only) } \\
\text { deposit rate (Eq. (8)) } \\
\left(U_{N E T}\right)\end{array}$ & 2.15 & 2.20 & -27.30 & 21.39 & 135 & -0.19 & 1.02 & -27.32 & 27.72 & 32 & 2.14 & 0.65 & -21.04 & 35.82 & 57 & $-1.46(0.14)$ & $-0.87(0.36)$ & $-0.46(0.65)$ \\
\hline $\begin{array}{l}\text { Net issuer underpricing } \\
\text { cost (retail only) prime } \\
\text { rate (Eq. (8)) }\end{array}$ & 1.59 & 1.24 & -27.32 & 20.75 & 135 & -0.52 & 0.85 & -27.32 & 27.49 & 32 & 2.03 & 0.55 & -21.04 & 35.30 & 57 & $-1.02(0.23)$ & $-0.41(0.68)$ & $-0.64(0.52)$ \\
\hline $\begin{array}{l}\text { Deposit rate during the } \\
\text { period January } 94 \text { to } \\
\text { December } 98\end{array}$ & 5.47 & 5.37 & 3.06 & 13.50 & 135 & 5.56 & 5.37 & 3.21 & 13.50 & 32 & 5.40 & 5.37 & 3.56 & 7.25 & 57 & $-0.01(0.99)$ & $-0.01(0.99)$ & $-0.04(0.97)$ \\
\hline $\begin{array}{l}\text { Prime rate during the } \\
\text { period January } 94 \text { to } \\
\text { December } 98\end{array}$ & 8.46 & 8.75 & 6.50 & 10.25 & 135 & 8.63 & 8.75 & 6.5 & 10.00 & 32 & 8.64 & 8.50 & 6.50 & 10.00 & 57 & $-1.42(0.16)$ & $-0.31(0.75)$ & $-1.20(0.23)$ \\
\hline $\begin{array}{l}\text { Number of days between } \\
\text { application closing } \\
\text { date and refund date }\end{array}$ & 6.66 & 7.00 & 3.00 & 11.00 & 135 & 5.78 & 6.00 & 3 & 10.00 & 32 & 5.67 & 6.00 & 3.00 & 12.00 & 57 & $-2.12(0.03)$ & $-4.45(0.00)$ & $-0.89(0.37)$ \\
\hline
\end{tabular}

This table reports the characteristics of the 224 IPOs listed on HKSE during the period 1994-1998. Eqs. (1) through (8) are described in Leung and Menyah (2006).

a Po and Pm are the offer price and the first day's market price, respectively. For comparison purposes, the HK\$ million figures are adjusted by the Hong Kong consumer price index. 
$(-0.52 \%)$. Thus, in the fixed price offering, the issuers of new shares in an IPO are more likely to gain rather than incur underpricing losses.

The non-parametric Mann-Whitney test (MWT) in Panel D of Table 2 suggests that pure fixed price IPOs differ significantly from fixed price IPOs in terms of market capitalisation, the amount raised at the IPO, the amount left on the table and underpricing. Furthermore, the pure fixed price sub-sample exhibits significantly higher issuer-related costs, including $U_{R}$ and $U_{N}$, and higher return on application funds, $R_{A F}$, than the fixed price sub-sample. However, the MWT indicates that the difference between these two sub-samples in terms of $U_{N E T}$ is not statistically significant.

\subsubsection{Bookbuilding offerings}

Panel C of Table 2 reports our findings based on the 57 bookbuilding IPOs that were brought to the Hong Kong market over the period 1994-1998. The average of the amount left on the table is HK\$154.14 million, representing $8.34 \%$ of the total amount raised. The first day initial returns range from $-38.66 \%$ to $222.12 \%$ with an average of $12.84 \%$. The bookbuilding sub-sample contains nearly $37 \%$ of overpriced IPOs, producing positive gains to the issuing companies and pre-IPO shareholders. The oversubscription rate of the retail (institutional) investors averages to 78.53 (8.9). Similar to the fixed price IPOs, the $R_{A F}$ associated with the bookbuilding sub-sample is based on the retail oversubscription rate applied only to the shares offered to the retail investors. The averages of $U_{R}, U_{T}$ and $U_{N}$ are $1.32 \%$, $0.65 \%$ and $2.32 \%$, respectively. The average $U_{N}$ represents $18 \%$ of the headline underpricing. The deposit (prime) rate based $R_{A F}$ of the bookbuilding sub-sample averages to $0.18 \%(0.29 \%)$. The standard $t$ statistic suggests that the average deposit (prime) rate based $R_{A F}$ is significantly different from zero at the conventional $1 \%$ level. ${ }^{10}$ This contradicts L\&M's argument that issuers hardly earn any interest from application funds in the case of bookbuilding offerings. The mean deposit (prime) rate based $U_{N E T}$ is $2.14 \%(2.03 \%)$, representing $16.67 \%$ (15.81\%) of the headline underpricing.

The non-parametric MWT in Panel D of Table 2 indicates significant differences between bookbuilding, pure fixed price and fixed price sub-samples in terms of the size of the IPO and the total amount raised. Panel $\mathrm{D}$ also shows that the average $R_{A F}$ of the pure fixed price IPOs is significantly higher than that of the bookbuilding counterparts. The pure fixed price IPOs incur significantly higher first day initial returns than the bookbuilding IPOs. However, we do not report any difference between the bookbuilding and fixed price sub-samples in terms of both the average first day initial returns and the average $R_{A F}$. The MWT also fails to reject the hypothesis and average $U_{N E T}$ is the same across the three IPO sub-samples.

\section{Do our results vary over time?}

To check robustness of our evidence across different time periods, we repeat our analysis on 334 Hong Kong IPOs issued between January 1999 and May 2007. ${ }^{11,12}$ A summary of the results is reported in Table 3 .

Table 3 shows that our results differ significantly from those generated using the L\&M's approach. L\&M's approach underestimates both the amount raised and amount left on the table by $11.14 \%$ and $13.94 \%$, respectively. This underestimation stems mainly from ignoring the exercise of overallotment options. In fact, 157 out of the 334 IPOs issued during the 1999-2007 period contain an exercised overallotment option. Our estimated $U_{N}$ and the L\&M based $U_{N}$ average to $2.2 \%$ and $1.88 \%$, respectively. The non-parametric Wilcoxon Sign Rank Test (WSRT) suggests that these two figures are significantly different at $1 \%$ level. The mean of our estimated prime (deposit) rate based $R_{A F}$ is $0.13 \%(0.29 \%)$, representing $5.91 \%$ (13.18\%) of the average $U_{N}$. Similarly, our estimated deposit (prime) rate based average $U_{N E T}$, of $2.07 \%(1.92 \%)$, makes up $20.15 \%$ (18.73\%) of the headline underpricing. The results from the L\&M's approach are very different from ours. Specifically, the L\&M's deposit (prime) rate based average

\footnotetext{
10 The details of this test are available upon request.

11 Note that we repeat our analysis over the entire period (1994-2007) and our conclusions remain unchanged. The detailed results are available upon request.

${ }^{12}$ We thank an anonymous referee for suggesting this robustness check.
} 
Table 3

Sample characteristics, issuer-related underpricing cost, interest earned on application funds for 334 IPOs issued in Hong Kong during the period 1999-2007: a direct comparison between L\&M's approach and our approach.

\begin{tabular}{|c|c|c|c|c|c|c|c|c|c|c|}
\hline & \multicolumn{3}{|c|}{ Full sample } & \multirow{2}{*}{$\begin{array}{l}\text { Pure fixed price } \\
(N=9) \\
\text { L\&M's approach } \\
\text { and our approach }\end{array}$} & \multicolumn{3}{|c|}{ Fixed price $(N=122)$} & \multicolumn{3}{|c|}{ Bookbuilding $(N=203)$} \\
\hline & $\begin{array}{l}\text { L\&M’s } \\
\text { approach }\end{array}$ & $\begin{array}{l}\text { Our } \\
\text { approach }\end{array}$ & WSRT & & $\begin{array}{l}\text { L\&M's } \\
\text { approach }\end{array}$ & $\begin{array}{l}\text { Our } \\
\text { approach }\end{array}$ & WSRT & $\begin{array}{l}\text { L\&M's } \\
\text { approach }\end{array}$ & $\begin{array}{l}\text { Our } \\
\text { approach }\end{array}$ & WSRT \\
\hline Amount raised (HK\$ m) & 2334.58 & 2594.65 & $-10.87^{* * *}$ & 52.71 & 99.23 & 104.29 & $-4.02^{* * *}$ & 3778.93 & 4204.22 & $-10.08^{* * *}$ \\
\hline Size of the firm at Po $(\mathrm{HK} \$ \mathrm{~m})^{\mathrm{a}}$ & 14599.99 & 14789.12 & $-8.07^{* * *}$ & 183.93 & 391.66 & 395.72 & $-2.40^{* *}$ & 23777.11 & 24086.7 & $-7.64^{* * *}$ \\
\hline Size of the firm at Pm (HK\$ m) & 16238.14 & 16460.07 & $-8.11^{* * *}$ & 206.98 & 401.11 & 412.56 & $-2.58^{* *}$ & 26465.74 & 26825.01 & $-7.66^{* * *}$ \\
\hline $\begin{array}{l}\text { Shares sold as \% of pre-IPO } \\
\text { shares (old }+ \text { new) }\end{array}$ & 35.11 & 37.66 & $-14.28^{* * *}$ & 46.67 & 33.27 & 34.38 & $-8.05^{* * *}$ & 35.78 & 39.44 & $-11.60^{* * *}$ \\
\hline $\begin{array}{l}\text { Shares sold as \% of pre-IPO } \\
\text { shares (old shares) }\end{array}$ & 3.76 & 9.49 & $-3.64^{* * *}$ & 4.18 & 4.91 & 10.12 & 0.163 & 3.05 & 8.88 & $-4.28^{* * *}$ \\
\hline $\begin{array}{l}\text { Amount left on the table (HK\$ } \\
\mathrm{m} \text { ) }\end{array}$ & 297.95 & 339.48 & $-9.64^{* * *}$ & 6.29 & 4.24 & 4.67 & $-2.48^{* *}$ & 487.4 & 555.49 & $-9.18^{* * *}$ \\
\hline Demand multiple retail & 107.39 & 107.39 & - & 121.75 & 31.37 & 31.37 & - & 157.27 & 157.27 & - \\
\hline Demand multiple institutional & 11.38 & 11.38 & - & - & 2.86 & 2.86 & - & 17.07 & 17.07 & - \\
\hline First day initial returns \% & 10.27 & 10.27 & - & 12.88 & 5.53 & 5.53 & - & 13.1 & 13.1 & - \\
\hline $\begin{array}{l}\text { Barry's issuer underpricing } \\
\text { cost \% (Eq. (1)) }\left(U_{D}\right)\end{array}$ & 6.36 & 6.55 & $-8.55^{* * *}$ & 10.96 & 0.07 & 0.15 & $1.67^{*}$ & 9.99 & 10.3 & $-8.86^{* * *}$ \\
\hline $\begin{array}{l}\text { Issuer underpricing cost of old } \\
\text { shares sold without dilution } \\
\text { (Eq. (3)) }\left(U_{S}\right)\end{array}$ & 1.17 & 1.36 & -1.07 & - & -0.39 & - & - & 1.95 & 2.24 & -1.34 \\
\hline $\begin{array}{l}\text { Issuer underpricing cost of old } \\
\text { shares not sold \% (Eq. (4)) } \\
\left(U_{R}\right)\end{array}$ & -0.53 & 1.71 & $-12.45^{* * *}$ & 3.22 & -0.18 & -0.04 & $-1.79^{*}$ & -0.89 & 2.71 & $-11.94^{* * *}$ \\
\hline $\begin{array}{l}\text { Issuer underpricing of partial } \\
\text { sale of pre-IPO shares with } \\
\text { dilution (Eq. (5)) }\left(U_{T}\right)\end{array}$ & 4.37 & 2.5 & $-5.51^{* * *}$ & 3.64 & 1.28 & 0.72 & $-2.12^{* *}$ & 6.8 & 3.91 & $-5.26^{* * *}$ \\
\hline $\begin{array}{l}\text { Issuer underpricing cost of new } \\
\text { shares issued and sold in the } \\
\text { IPO \% (Eq. (6)) }\left(U_{N}\right)\end{array}$ & 1.88 & 2.2 & $-8.39^{* * *}$ & 3.73 & 0.3 & 0.35 & $-1.94^{*}$ & 2.76 & 3.27 & $-8.86^{* * *}$ \\
\hline $\begin{array}{l}\text { Interest income on application } \\
\text { funds }(\mathrm{HK} \$ \mathrm{~m}) \text { retail deposit } \\
\text { rate }\end{array}$ & 197.83 & 15.65 & $-15.62^{* * *}$ & 58.22 & 2.23 & 0.27 & $-9.58^{* * *}$ & 324.14 & 25.58 & $-12.35^{* * *}$ \\
\hline $\begin{array}{l}\text { Interest income on application } \\
\text { funds }(\mathrm{HK} \$ \mathrm{~m}) \text { retail prime } \\
\text { rate }\end{array}$ & 392.2 & 30.95 & $-15.62^{* * *}$ & 96.72 & 5.17 & 0.61 & $-9.58^{* * *}$ & 642.17 & 50.56 & $-12.35^{* * *}$ \\
\hline
\end{tabular}




\begin{tabular}{|c|c|c|c|c|c|c|c|c|c|c|}
\hline $\begin{array}{l}\text { Interest income as \% of first day } \\
\text { firm's market value retail } \\
\text { deposit rate }\end{array}$ & 1.25 & 0.13 & $-15.67^{* * *}$ & 0.03 & 0.24 & 0.04 & $-9.55^{* * *}$ & 1.91 & 0.19 & $-12.25^{* * *}$ \\
\hline $\begin{array}{l}\text { Interest income as \% of first day } \\
\text { firm's market value retail } \\
\text { prime rate }\end{array}$ & 2.76 & 0.29 & $-15.80^{* * *}$ & 0.05 & 0.66 & 0.09 & $-9.58^{* * *}$ & 4.14 & 0.42 & $-12.35^{* * *}$ \\
\hline $\begin{array}{l}\text { Net issuer underpricing cost } \\
\text { (retail only) deposit rate (Eq. } \\
(8))\left(U_{N E T}\right)\end{array}$ & 1.41 & 2.07 & $-14.90^{* * *}$ & 3.7 & 0.06 & 0.31 & $-8.59^{* * *}$ & 2.14 & 3.08 & $-11.87^{* * *}$ \\
\hline $\begin{array}{l}\text { Net issuer underpricing cost } \\
\text { (retail only) prime rate (Eq. } \\
\text { (8)) }\end{array}$ & -0.26 & 1.92 & $-15.39^{* * *}$ & 3.68 & -0.36 & 0.26 & $-9.07^{* * *}$ & -0.36 & 2.85 & $-12.11^{* * *}$ \\
\hline $\begin{array}{l}\text { Deposit rate during the period } \\
\text { January } 99 \text { to May } 07\end{array}$ & 3.14 & 3.14 & - & 4.49 & 3.16 & 3.16 & - & 3.07 & 3.07 & - \\
\hline $\begin{array}{l}\text { Prime rate during the period } \\
\text { January } 99 \text { to May } 07\end{array}$ & 6.8 & 6.8 & - & 7.94 & 6.72 & 6.72 & - & 6.8 & 6.8 & - \\
\hline $\begin{array}{l}\text { Number of days between } \\
\text { application closing date and } \\
\text { refund date }\end{array}$ & 5.84 & 5.84 & - & 6 & 5.47 & 5.47 & - & 6.05 & 6.05 & - \\
\hline
\end{tabular}

This table reports the characteristics of the 334 IPOs listed on HKSE during the period 1999-2007 table. Eqs. (1) through (8) are described in Leung and Menyah (2006).

a Po and Pm are the offer price and the first day's market price, respectively. For comparison purposes, the HK\$ million figures are adjusted by the Hong Kong consumer price index. WSRT refers to the non-parametric Wilcoxon Sign Rank Test.

* indicate significance at $1 \%$ levels (two-tailed).

** indicate significance at $5 \%$ levels (two-tailed).

*** indicate significance at $10 \%$ levels (two-tailed). 
$R_{A F}$, of $1.25 \%$ (2.76\%), forms $66.48 \%$ (46.80\%) of the average $U_{N}$. Similarly, the L\&M's deposit (prime) rate based average $U_{N E T}$, of $1.41 \%(-0.26 \%)$, accounts for $11.73 \%(-2.53 \%)$ of the overall heading underpricing. The WSRT rejects the hypothesis that L\&M's approach and ours produces the same $R_{A F}$ and $U_{N E T \text {. }}$

Table 3 also reports the results by IPO offering methods. 9, 122, and 203 of the Hong Kong IPOs issued during the period 1999-2007 were offered using pure fixed price, fixed price and bookbuilding methods, respectively. Table 3 shows that the L\&M's approach overestimates $R_{A F}$ and underestimates $U_{N E T}$ of both fixed price and bookbuilding offerings. Specifically, the L\&M's deposit (prime) rate based $R_{A F}$ associated with the fixed price and bookbuilding offerings are $0.24 \%(0.66 \%)$ and $1.91 \%$ (4.14\%), respectively. These figures drop significantly to $0.04 \%(0.09 \%)$ and $0.19 \%(0.42 \%)$ when our approach is adopted. Similarly, the L\&M's deposit (prime) rate $U_{N E T}$ of the fixed price and bookbuiding sub-samples increase significantly from $0.06 \%(-0.36 \%)$ and $2.14 \%(-0.36 \%)$ to $0.31 \%(0.26 \%)$ and $3.08 \%$ (2.85\%) following the application of our approach. Since L\&M's approach is valid in the case of pure fixed price IPOs, it produces identical results to ours for this group of IPOs.

\section{Conclusion}

The issuer underpricing cost of new share issues, $U_{N}$, of the Hong Kong IPOs issued during the period 1994-1998 averages to $2.5 \%$. This average represents about $16 \%$ of the headline underpricing. When interest on application funds is taken into account, the net $U_{N}$, or $U_{N E T}$, decreases to about $11 \%$ of the headline underpricing. These results are different from L\&M who show that $U_{N}$ is reduced from $14 \%$ to $7 \%$ of the headline underpricing after adjusting for the interest earned on application funds. This difference in the results is likely to be caused by the fact that L\&M's results may be biased towards the pure fixed price IPOs. In the pure fixed price offerings, a single oversubscription rate applies to all shares on offer. However, in both fixed price and bookbuilding IPOs, shares on offer are split between the retail and institutional investors. This suggests that two oversubscription rates are applicable. Given that only retail investors are required to make upfront payment for the shares, the retail oversubscription rate should be applied to the shares offered to the retail investors in order to calculate the interest earned on application funds. Thus, the offering method matters in determining the interest income from application funds.

This study shows that the issuer-related underpricing costs and the return on application funds depend on the IPO offering methods. Over the period 1994-1997, the $U_{N}$ of the pure fixed price, fixed price and bookbuilding sub-samples averages to $3.11 \%, 0.21 \%$ and $2.32 \%$, representing $15.60 \%, 4.61 \%$ and $18.07 \%$ of the headline underpricing, respectively. After accounting for the interest on application funds, the average $U_{N E T}$ represents about $12.54 \%,-4.17 \%$ and $16.67 \%$ of the headline underpricing in the case of pure fixed price, fixed price and bookbuilding sub-samples, respectively. Consistent with L\&M, and regardless of the offering methods, we find that pre-IPO investors either sell a very small proportion or none of their pre-IPO shares. This evidence supports the view that pre-IPO shareholders time the sale of their holdings at an IPO in order to avoid transferring their wealth to the new investors. We repeat our analysis on the Hong Kong IPOs issued during the period 1999-2007 to show that our conclusions remain valid across different time period.

The approach proposed in this study can be applied to all IPO markets with the same subscription process as Hong Kong. UK, Australia, India, Indonesia, Singapore, and Thailand are among the countries in which (some) investors are required to pay IPO subscription funds without knowing whether or not they would receive an allocation (see, for example, Chowdhry and Sherman, 1996). Underwriters in these countries distinguish between the shares allocated to retail investors and those set aside for institutional investors, when shares are offered via fixed price or bookbuilding methods. This distinction results in two oversubscription rates. L\&M (2006) estimate the interest earned on the application funds using a single oversubscription rate applied to all shares on offer. However, we account for the fact that retail investors and institutional investors receive separate share allocations when we estimate the amount of interest earned on the subscription funds. 


\section{Acknowledgements}

The authors would like to thank Professor Booth, editor of this journal, and an anonymous referee, whose insightful comments helped us improve the paper immensely. Professor Mark Freeman, Professor Roszaini Haniffa, and Musa Mangena deserve special thanks.

\section{References}

Chowdhry, B., Sherman, N., 1996. International differences in oversubscription and underwriting of IPOs. Journal of Corporate Finance 2, 359-381.

Fung, J.K.W., Cheng, L.T.W., Chan, K.C., 2004. The impact of the costs of subscription on measured IPO returns: the case of Asia. Journal of Corporate Finance 10, 459-465.

Leung, J., Menyah, K., 2006. Issuer-oriented underpricing costs in initial public offers: evidence from Hong Kong. Journal of Corporate Finance 12, 897-905.

Ljungqvist, A.P., Wilhelm, W.J., 2002. IPO allocations: discriminatory or discretionary. Journal of Financial Economics 65, 167-201.

Loughran, T., Ritter, J.R., Rydqvist, K., 1994. Initial public offerings: international insights. Pacific-Basin Finance Journal 2 , 165-199.

McGuiness, P., 1993. An examination of the underpricing of initial public offerings in Hong Kong: 1980-1990. Journal of Business Finance and Accounting 19, 165-186.

Ritter, J.R., 2003. Differences between European and American IPO markets. European Financial Management 9 (4), $421-434$. 